\title{
Composite Performance Index for Sustainability
}

\author{
G Satish Pandian ${ }^{1}$, N Jawahar ${ }^{2}$ and SP.Nachiappan ${ }^{3}$ \\ 1,2 (Dept. of Mechanical Engineering, Thiagarajar College of Engineering, Madurai- 625015, India) \\ ${ }_{3}^{3}$ (Dept. of Entrepreneurship, Marketing and Management Systems, Nottingham University Business School \\ China)
}

\begin{abstract}
Economic, Social and Socio-Economic performances are the three pillars of sustainability. Numerous dimensions address each of their performances. Each dimension contributes towards sustainable performance measure. This necessitates an index to account the various dimensions of the sustainability. Since multiple dimensions are associated with sustainable performance, the index warrants composition of many dimensions. The objective of the paper is to develop a Composite Performance Index (CPI) to measure and evaluate the industries in terms of sustainable performances. The development of CPI can be addressed as one of Multi-Attribute Decision Making (MADM) problems. This paper presents a MADM model developed for 'CPI for sustainability' and illustrates its application with case study examples. The CPI developed for sustainability can be useful for assessing the performance of industries as well identifying environmental practices to be followed for their sustainability.
\end{abstract}

Keywords: Composite Performance Index, Environmental Sustainability, Multi-Attribute Decision Models, Analytical Hierarchy Process.

\section{NOMENCLATURE}

$a_{i j}-$ Index for performance score of $j^{\text {th }}$ industry for $i^{\text {th }}$ dimension

$\mathrm{i}$ - Index for dimension (criterion) of sustainability

$\mathrm{j}$ - Index for industry (alternative)

$\mathrm{k}$ - Index for performance indices ( 1 to 5 )

$\mathrm{n}$ - Number of industries (alternatives) to be compared

$\mathrm{A}_{\mathrm{j}-}$ Alternatives (Industry)

$\mathrm{C}_{\mathrm{i}}-$ Criterion attributes

$\mathrm{m}$ - Number of dimensions (criteria) considered

$S_{i}^{k}-$ Score for $i^{\text {th }}$ dimension $(1-5)$ to its $k^{\text {th }}$ level

$S_{j}{ }^{i}$ - Performance score of $j^{\text {th }}$ industry for $i^{\text {th }}$ dimension

$\mathrm{W}_{\mathrm{e}}$ - Weight for economic sustainability

$\mathrm{W}_{\mathrm{s}}$ - Weight for social sustainability

$\mathrm{W}_{\text {se }}$ - Weight for socio-economic sustainability

$\mathrm{W}_{\mathrm{i}}^{\mathrm{e}}$ - Importance of $\mathrm{i}^{\text {th }}$ dimension in economic sustainability

$\mathrm{W}_{\mathrm{i}}^{\mathrm{s}}$ - Importance of $\mathrm{i}^{\text {th }}$ dimension in social sustainability

$\mathrm{W}_{i}^{\text {se }}$ - Importance of $i^{\text {th }}$ dimension in socio-economic sustainability

$\mathrm{W}_{\mathrm{i}-}$ Weight for $\mathrm{i}^{\text {th }}$ dimension / criterion /attributes

\section{Introduction}

The term "sustainable development", coined by the International Union for Conservation of Nature s 1980 World Conservation Strategy, states that for development to be sustainable it must be taken account of social and ecological factors, as well as economic ones. The Brundtland Report (1987) provides the most popular notion of sustainability (sustainable development): development that meets the needs of the present without compromising the ability of future generations to meet their own needs. Markandya and Pearce (1988) reinstated that the sustainable development means the use of renewable natural resources in a manner that does not eliminate or degrade them or otherwise diminish their usefulness for future generations. They further stated that sustainability might be redefined so that the use of resources today should not reduce real incomes in the future because sustainability requires the conditions necessary for equal access to the resource base be met for each subsequent generation. These broad definitions of sustainable development give rise to multiple interpretations on what is to be sustained, what is to be developed, and how to link environment and development (Tanguay et al., 2010). The concept of sustainable development is charged with complexities as it involves and balances several different goals, content types, approaches, aspirations and desires. If it is to be analyzed and carried out on the basis of a decision-making process, sustainability must be measured in terms of multiple dimensions. This paper concentrates on sustainable performance measurement. 
There are many ways to measure sustainable development; each of which provides potentially useful, though different, insights for policy makers, academics and the general public. As a multifaceted concept, sustainability requires aggregate measures (Hanley et al. 1999). Future economic progress will be increasingly dependent on the sustained integrity of the resource and environmental base (Hamrin, 1983). One way to measure the economy is to assess the value of non-monetary goods and services and measure the rate of infant mortality, life expectancy of people, educational opportunities offered by the state, family stability, environmental data, and health care for all people. Another measure is to quantify human benefits (in terms of education, health care, elder care, etc.) provided by each unit of output. Measuring the gap between the most fortunate and the least fortunate in our society, for example, tells us how well or poorly we are doing in creating an economy that does not benefit some at the expense of others. Sustainable performance, which integrates, economic, ecological/ environmental and social aspects, is the appropriate performance measure of the future (Hermann et al 2008, Yarong and Xin 2011 and Gimenez et al 2012). It may be presumed that sustainability deals with three kinds of measures and are: economical, social and socio-economic (environmental). Each kind has multiple instruments to address the sustainable performance of industries. The development of the designs shows that not one measure should be considered but a combination of measures, resulting in the competitive performance. Hizsnyik and Toth (2010) stated that Composite Sustainable Development Indexes allow the integration of environmental, economic and social concerns for sustainability evaluation. Such indexes might help in the development and monitoring of national strategies for sustainable development. The main objective of this research is to develop a composite index for evaluating the industries for their sustainable performance.

Finding the appropriate level of complexity for descriptions and models is a necessary precondition for adequate analysis and to avoid wrong prognoses. Literature presents many models and methods for handling multi-criteria evaluations. The family of Multi-Attribute Utility Theory (MAUT) methods has the capability of aggregating the different criteria into a function, (Keeney and Raiffa, 1976). The basis of MAUT is the use of utility functions. Utility functions can be applied to transform the raw performance values of the alternatives against diverse criteria, both factual (objective, quantitative) and judgmental (subjective, qualitative), to a common, dimensionless scale. In practice, the intervals $[0,1]$ or $[0,100]$ are used for this purpose. Utility functions play another very important role: they convert the raw performance values so that a more preferred performance obtains a higher utility value. The Analytic Hierarchy Process (AHP), proposed by Saaty (1980), is the widely accepted method for handling multi-attribute evaluations. It provides a single index to address all the dimensions of the alternatives. The basic idea of the approach is to convert subjective assessments of relative importance to a set of overall scores or weights. The methodology of AHP is based on pair-wise comparisons of the following type 'How important is criterion $C_{i}$ relative to criterion $C_{j}$ ?' Questions of this type are used to establish the weights for criteria and similar questions are to be answered to assess the performance scores for alternatives on the subjective (judgmental) criteria. This paper proposes an AHP based methodology for developing Composite Performance Index for sustainability, which needs to address/incorporate various raw performance values (dimensions) of sustainable performances of economic, social and environmental into a common dimensionless scale. The rest of the paper is organized as follows: Section 2 deals with the dimensions of sustainability. Section 3 describes the evaluation model of the problem and illustrates the AHP process adopted for the establishment of the CPI. Section 4 discusses the results of the case studies. The summary of the research along with future directions are presented in the conclusion section 5.

\section{Dimensions Of Sustainability}

The performance studies on environmental concerns consider various dimensions to each of the three kinds of sustainability viz. economic, social and socio-economic. This section delineates their definitions and dimensions.

\subsection{Economic Sustainability}

It is defined as "The use of various strategies for employing existing resources optimally so that a responsible and beneficial balance can be achieved over the longer term". Within a business context, economic sustainability involves using the assorted assets of the company efficiently to allow it to continue functioning profitability over time. An Economic Indicator is a piece of economic data, usually of macroeconomic scale, that is used by investors to interpret current or future investment possibilities and judge the overall health of any economy. Gross Domestic Product (GDP) is an economic indicator that measures the earnings and profit of production that takes place within a given country. As the dominant accounting framework and gauge for measuring the wealth, and status of a nation, GDP represents a primary feedback mechanism and driver of national policy. Because an increase in GDP is seen as an increase of the well-being of a nation. GDP defines the economic priorities and problems of national policy. The other selective economic indicators are: Consumer spending (Personal Income and Spending, Car and Truck Sales, Retail Sales, Home Sales, Consumer Credit, Consumer Confidence Measures), Industrial Activity (Industrial Production and Capacity Utilization, Housing 
Starts/Building Permits, Durable Goods Orders, Construction Expenditures, Business Inventories and Sales, Factory Orders and Manufacturing Inventories, Productivity and Costs), Government Spending and Foreign trade (Federal Budget, Merchandise Trade Balance, Current Account Balance, Exports, Foreign Industrial Productions, Global Manufacturing Purchasing Managers Index), Labor Market (Payroll employment and Unemployment rate Employment Cost Index, Unemployment Insurance Claims), Inflation (Producer Price Index, Consumer Price Index), and some specialized Indicators.

\subsection{Social Sustainability}

Black (2004) has defined social sustainability as "the extent to which social values, social identities, social relationships and social institutions can continue into the future". Torjman (2000) characterizes social sustainability as follows: "From a social perspective in particular, human wellbeing cannot be sustained without a healthy environment and is equally unlikely in the absence of a vibrant economy". Gilbert et al. (1995) perceive the social pillar of sustainable development as follows: "Social sustainability requires that the cohesion of society and its ability to work towards common goals be maintained. Individual needs, such as those of health and well-being, nutrition, shelter, education and cultural expression should be met". The dimensions of social sustainability are classified under three basic aspects of human development longevity, knowledge, and a decent standard of living. Longevity is measured by life expectancy at birth; knowledge is measured by a combination of the adult literacy rate and the combined primary, secondary, and tertiary gross enrollment ratio; and standard of living is measured by adjusted GDP per capita.

\subsection{Socio - Economic (Environmental) Sustainability}

Environmental Sustainability is defined as "The maintenance of the factors and practices that contribute to the quality of environment on a long-term basis". Environmental sustainability is the rates of renewable resource harvest, pollution creation, and non-renewable resource depletion that can be continued indefinitely. The term itself was probably first coined by scientists at the World Bank and Originally, the term "environmentally responsible development" was used (World Bank, 1992). Subsequently, "environmentally sustainable development" was employed (Serageldin and Streeter, 1993). Finally, the concept of environmental sustainability was developed (Goodland, 1995). Goodland's conceptualization of environmental sustainability fits into the resource-limited ecological economic framework of "limits to growth". He also identifies environmental sustainability as a set of constraints on the four major activities regulating the scales of the human economic subsystem: "the use of renewable, nonrenewable resources on the source side, pollution and waste assimilation on the sink side". Holdren et al. (1995) define environmental sustainability by focusing on its biogeophysical aspects. Biophysical sustainability means maintaining or improving the integrity of the life supporting systems of the Earth. Sustaining the biosphere with adequate provisions for maximizing future options includes enabling current and future generations to achieve economic and social improvement within a framework of cultural diversity while maintaining (a) biological diversity and (b) the biogeochemical integrity of the biosphere by means of conservation and proper use of air, water, and land resources. The term environmental sustainability has gradually been established. For example, the Commissioner for Environmental Sustainability of the Australian State of Victoria defined environmental sustainability as "the ability to maintain the qualities that are valued in the physical environment" (Sutton, 2004). Prescott-Allen (2001) indexed Environmental Sustainability indicators under two broad categories as Human Wellbeing index and Ecosystem Wellbeing index. Human Wellbeing index combines 36 indicators of health, population, wealth, education, communication, freedom, peace, crime, and equity and so on, and 51 indicators of land, biodiversity, water quality and supply, air quality and global atmosphere, and energy and resource use pressures into an Ecosystem Wellbeing index. The environment that figures in environmental sustainability falls under air, energy, green areas, noise, transport, waste, water, territory and demographic dimensions are (Donatiello, 2001):

Air: Air pollutants in urban areas, Density of fixed monitoring sites, Number of monitored air pollutants and Number of days of traffic restriction (affecting non catalyzed passenger cars).

Energy: Electricity consumption per capita, Electricity consumption by sector (residential, industrial, agricultural, commercial/services), Gas methane consumption per capita, Gas methane consumption by sector (residential, heating, others) and Implementation of Environment Energy Plan.

Green areas: Density of public green areas, Density of public green by typology (urban parks, historic green areas, neighborhood green, green belts, special green areas - school gardens, botanical gardens, green playgrounds, etc), Building up of new green areas in the year, Census of green urban areas in the year and Implementation of Green Urban Plan.

Noise: Number of fixed noise, monitoring sites implemented noise barriers, Number of implemented noise monitoring campaigns, Number of requests of interventions for noise disturbance by typology of noise sources (industrial activities, traffic, recreation activities), Number of municipality's authorizations for temporary acoustic polluting activities by typology (musical events, sport events, noisy equipment, others) Number of fines 
for traffic noise due to passenger cars, Implementation of Acoustic Zoning Plan, Implementation of Noise and Abatement Plan.

Transport: Rail infrastructure length, Density of railway, railway lines per $100 \mathrm{~km}$, Density of lines by typology, railway, tram, metro, trolleybus, Passenger car density Cars Road vehicle density Road vehicle per 1000 inhabitants, Density of taxis, Taxi per 1000 inhabitants Number of road vehicles by categories (e.g. passenger cars, buses, motorbikes, lorries ), by fuel type (gasoline, unleaded gasoline, diesel, others) and by average age, Density of pedestrian areas, Cycling paths length, Density of restricted traffic zones, restricted traffic zones, Number of paying car parks on roads, Number of free car parks in proximity to public transport, Number of public transport, passenger by bus, tram, metro, trolleybus, Implementation of Urban Traffic Plan , Innovative traffic control programmes.

Waste: Collection of municipal waste Kg per capita, Separate collection of municipal waste by typology (paper, glass, plastic, aluminium, iron material, wood material, organic waste, etc) $\mathrm{Kg}$ per capita, Number of waste treatment and waste disposal facilities, Availability and use of recycling facilities inside the commune or in other commune Density of waste dustbin, Dust bin per 10.000 inhabitants and per km, Number of dustcart Dust cart per 10.000 inhabitants Number of campaign to improve separate collection of waste from households, Number of fines for illegal waste disposal, Fines per 10.000 inhabitants.

Water: Water consumption per capita, Water consumption by residential use per capita, Water consumption by sector (residential, industrial, agricultural, commercial/services, others) and Number of waste water treatment plants by typology.

Territorial and demographic data: Percent of population connected to waste water treatment plants, Territorial surface of the city, Population density and Number of Households.

\subsection{Summary}

The deliberations on the three kinds of sustainability reveal the following:

- Since the "three pillars" concept is introduced, it has gradually been acknowledged that economic and social sustainability do indeed have their own merits, as well as specific and concrete meaning as a part of human, social, political or economic development.

- Although economical measures are used to evaluate production systems, it is argued that these measures result in wrong conclusions. Being an economic measure, the productivity is not an adequate measure to determine the manufacturing performance. As described, the competitive performance should be the measure to support management decisions. Such a measure depends upon a lot of specialized performance measures, like economic performance, technical performance, etc. In practice, the technical measures described in the literature are inadequate to determine the technical performance. Therefore, a measure for the technical performance is introduced which is clear, timely and relevant for the shop floor and the operating departments, and which can be used to compare design alternatives of production systems and to control the production process.

- Social sustainability is gaining growing respect and is more and more used and quoted (UNDP, 2004). A specific definition of the social dimension of sustainable development is less clear-cut (Martin, 2003). Understandably, the diversity of economic, social and cultural conditions in individual countries makes development of a uniform definition of social sustainability very difficult.

- Sustainable development used to be more or less understood as social and economic development that should be environmentally sustainable. In light of such understanding, it is necessary to closely scrutinize the third pillar to focus on the definition of environmental sustainability and ask for a full clarification of its precise meaning.

- Application of sustainability indicators to measure welfare and development at local scales is strategic to evaluate the short and long term effects of strategies.

- The approaches to the economic, social and environmental dimensions of sustainable development are diverse.

\section{Model For Sustainability Evaluation}

This section presents the model for the establishment of Composite Performance Index for Sustainability in line with generalized multi-criteria evaluation model. Any (MADM) model involves five main stages and they are (San Cristóbal Mateo 2012):

Stage 1(Defining the problem, generating alternatives and establishing criteria): A decision-making problem should start out by clearly defining the problem, discerning the alternatives, identifying the actors, the objectives and any points in conflict, together with the constraints, the degree of uncertainty and the key issues. After this, the problem can be framed indicating the evaluation criteria.

Stage 2 (Assigning criteria weights): The next step includes the assignment of criteria weights. These weights, that show the relative importance of criteria in the multi-criteria problem under consideration, can be determined 
by techniques such as AHP and Sismos approach.

Stage 3 (Construction of the evaluation matrix): The phase in which the model is built constitutes a process from which the 'essence' of the problem is extracted from the complex picture drawn up so that the problem can be assessed adequately. At the end of this step, the MADM problem can be expressed in matrix form. Each decision table (also called decision matrix) in MADM methods has four main parts, namely: (a) alternatives (b) attributes (c) weight or relative importance of each attribute, and (d) measures of performance of alternatives with respect to the attributes. The decision matrix is shown in Table I. It shows alternatives, $\mathrm{Aj}$ (for $j=1,2, \ldots, n$ ), criteria attributes $C_{i}\left(\right.$ for $i=1,2, \ldots ., m$ ), weights of attributes, $W_{i}$ (for $i=1,2, \ldots ., m$ ) and the measures of performance of alternatives, $a_{i j}$ (for $i=1,2, \ldots ., m ; j=1,2, \ldots ., n$ ). It may be added here that all the elements in the decision table must be normalized to the same units so that all the possible attributes in the decision problem can be considered. Table I shows the typical decision matrix.

Table I Decision matrix

\begin{tabular}{|l|c|c|c|c|c|c|c|}
\hline \multirow{2}{*}{ Criterion 'i' } & \multirow{2}{*}{ Weight $\mathrm{W}_{\mathrm{i}}$} & \multicolumn{6}{|c|}{ Industry 'j' } \\
\cline { 3 - 7 } & & 1 & 2 & & $\mathrm{j}$ & & $\mathrm{n}$ \\
\hline$C_{1}$ & $\mathrm{~W}_{1}$ & $a_{11}$ & $a_{12}$ & $\ldots$ & $a_{1 \mathrm{j}}$ & $\ldots \ldots \ldots .$. & $a_{1 n}$ \\
\hline$C_{2}$ & $\mathrm{~W}_{2}$ & $a_{21}$ & $a_{22}$ & $\ldots$ & $a_{2 \mathrm{j}}$ & $\ldots \ldots \ldots .$. & $a_{2 n}$ \\
\hline & & & & & & $\ldots \ldots \ldots .$. & \\
\hline$C_{\mathrm{i}}$ & $\mathrm{W}_{\mathrm{i}}$ & $a_{\mathrm{i} 1}$ & $a_{\mathrm{i} 2}$ & $\ldots$ & $a_{\mathrm{ij}}$ & $\ldots \ldots \ldots .$. & $a_{\mathrm{in}}$ \\
\hline & & & & & & $\ldots \ldots \ldots .$. & \\
\hline$C_{\mathrm{m}}$ & $\mathrm{W}_{\mathrm{m}}$ & $a_{\mathrm{m} 1}$ & $a_{\mathrm{m} 2}$ & $\ldots$ & $a_{\mathrm{mj}}$ & $\ldots \ldots \ldots .$. & $a_{\mathrm{m} n}$ \\
\hline
\end{tabular}

Stage 4 (Selecting the appropriate method): A multi-criteria method must be selected and applied to the problem under consideration in order to evaluate and rank alternatives. The data and the degree of uncertainty are key factors for the decision-maker when selecting among several multi-criteria methods.

Stage 5 (Ranking the alternatives): Finally, the alternatives' ranking is ordered and the best ranked alternative is proposed as a solution. With respect to the objective of this paper, the model for sustainable evaluation is formulated as MADM and delineated below.

\subsection{Problem description}

This section presents the objective, criteria influencing the objective and the alternatives for evaluations of the problem under consideration.

Problem objective: The primary goal of the research is "Sustainable performance analysis of Environmental Practices to evolve best ERMS practices to each sector of manufacturing industry". This necessitates establishing a common scale for the measurement of sustainable practices of industries, which becomes the objective of this paper. On this concern, the problem under study focuses on "Development of a composite index for evaluating the industries for their sustainable performance".

Criteria: The criteria associated with this study are the KPIs of sustainability. The need for sustainability arises to identify the environmental regulation practices for longevity of industries and society. Literature addresses variety of numerous dimensions for sustainable development. It is cumbersome to account all the dimensions. Besides, some of them are redundant and vague. Hence, selective dimensions need to be identified as key performance indicators that are quantifiable measurements, agreed to beforehand, and reflect the critical evaluation of the primary need of measurement, (Kellen, 2003). On this consideration, 12 dimensions, 4 each for economic, social and socio-economic sustainability. Table II presents the dimensions selected along with reason for consideration.

Alternatives: Industries can be classified into different sectors/ categories as process industries, discrete part manufacturing industries, service industries, and so on. They can also be classified as small, medium and large industries depending upon their volume of production and turn over. Each category may perform differently with respect to sustainability. Hence, the alternatives are different categories of industry.

Table II key performance dimensions of sustainability

\begin{tabular}{|l|l|ll|}
\hline Dimension 'i & \multicolumn{2}{|c|}{ Criterion/Dimension } & \multicolumn{2}{c|}{ Reason } \\
\hline \multicolumn{2}{|l|}{ Economic sustainability } & $\bullet$ & $\begin{array}{l}\text { Indicator of production and operation efficiency. } \\
\bullet\end{array}$ \\
\hline 2. & Income/ profit & $\bullet$ & $\begin{array}{l}\text { Factor of GDP contribution } \\
\text { Indicator of gross demand }\end{array}$ \\
\hline
\end{tabular}




\begin{tabular}{|c|c|c|}
\hline 3. & Turn over & $\begin{array}{l}\text { - } \quad \text { Measure of monetary soundness } \\
\text { - }\end{array}$ \\
\hline \multirow[t]{2}{*}{4.} & Return on investment & $\begin{array}{ll}- & \text { Indicator of business risk. } \\
\text { - } & \text { Indicator of percentile savings }\end{array}$ \\
\hline & \multicolumn{2}{|l|}{ Social sustainability } \\
\hline 5. & Increase in Literacy rate & $\begin{array}{l}\text { - Measure of employee education that is an indicator } \\
\text { of cultural development } \\
\text { - Indicator of knowledge level leading harmony } \\
\text { among people. }\end{array}$ \\
\hline 6. & Drop in accidental rate & $\begin{array}{l}\text { - Indicator of adherence of safety practices leading } \\
\text { to productivity through avoidance wastes } \\
\text { - Gauge for social responsibility towards better } \\
\text { living }\end{array}$ \\
\hline 7. & Fall In crime rate & $\begin{array}{l}\text { - Indicator of adherence of laws, rules and } \\
\text { regulations contributing to societal growth } \\
\text { - Measure of discipline and ethics towards } \\
\text { community development }\end{array}$ \\
\hline \multirow[t]{2}{*}{8.} & $\begin{array}{l}\text { Decline in patient admission in } \\
\text { hospitals }\end{array}$ & $\begin{array}{l}\text { Parameter of healthiness of human } \\
\text { - Indicator of the adaptation and implementation of } \\
\text { health practices }\end{array}$ \\
\hline & \multicolumn{2}{|c|}{ Socio-Economic sustainability } \\
\hline 9. & Increase of per capita income & $\begin{array}{l}\text { - Indicator of standard of living and comfort } \\
\text { - Measure of societal care with respect to future } \\
\text { generation }\end{array}$ \\
\hline 10. & $\begin{array}{l}\text { Improved transport and } \\
\text { communication facilities }\end{array}$ & $\begin{array}{l}\text { - Indicator of technological developments in } \\
\text { transport and communication sectors showing the } \\
\text { economic growth } \\
\text { - Indirect inverse measure of Air, Noise, } \\
\text { Electromagnetic pollutions that are essentially to be } \\
\text { controlled for preserving the atmosphere. }\end{array}$ \\
\hline 11. & $\begin{array}{l}\text { Better regularity of the } \\
\text { employee }\end{array}$ & $\begin{array}{ll}\bullet & \text { Parameter of labour productivity } \\
& \text { Indicator of conscientious to society }\end{array}$ \\
\hline 12. & $\begin{array}{l}\text { Improved Unity and Morale of } \\
\text { the employees }\end{array}$ & $\begin{array}{l}\text { - Indicator of cooperation and team work } \\
\text { leading to increase in economy } \\
\text { - } \quad \text { Parameter of corporate social responsibility }\end{array}$ \\
\hline
\end{tabular}

\subsection{Determination of Dimension weights}

One of the most crucial steps in the application of any MADM is the accurate estimation of the criterion weight. It is crucial in methods where there is a need to elicit qualitative information from the decisionmaker. Very often qualitative data cannot be known in terms of absolute values. Therefore, many decisionmaking methods attempt to determine the relative importance, or weight of the alternatives in terms of each criterion involved in the problem (Triantaphyllou and Mann, 1995). This section illustrates how the weights to the dimensions of sustainability are estimated. AHP, an approach based on pair wise comparisons and proposed by Saaty (1980), has long attracted the interest of many researchers. Pair wise comparisons are used to determine the relative importance of each dimension in terms of each criterion. In this approach, the decisionmaker/expert has to express his opinion about the value of one single pair wise comparison at a time. Usually, the decision-maker has to rate his answer among choices. Table III shows the typical scale of absolute numbers for intensity of importance, along with definitions and explanation.

Table III Fundamentals Scale of Absolute Numbers

\begin{tabular}{|c|l|l|}
\hline $\begin{array}{c}\text { Intensity of } \\
\text { Importance }\end{array}$ & \multicolumn{1}{|c|}{ Definition } & \multicolumn{1}{c|}{ Explanation } \\
\hline 1 & Equal importance & $\begin{array}{l}\text { Two activities contribute equally to the } \\
\text { objective }\end{array}$ \\
\hline 3 & Weak importance of one over another & $\begin{array}{l}\text { Experience and judgment slightly } \\
\text { favour one activity over another }\end{array}$ \\
\hline
\end{tabular}




\begin{tabular}{|c|l|l|}
\hline 5 & Essential or strong importance & $\begin{array}{l}\text { Experience and judgment strongly } \\
\text { favour one activity over another }\end{array}$ \\
\hline 7 & Demonstrated importance & $\begin{array}{l}\text { An activity is strongly favouring and } \\
\text { its dominance demonstrated in practice }\end{array}$ \\
\hline 9 & Absolute importance & $\begin{array}{l}\text { The evidence favouring one activity } \\
\text { over another is } \\
\text { of the highest possible order of } \\
\text { affirmation }\end{array}$ \\
\hline $2,4,6,8$ & $\begin{array}{l}\text { Intermediate values between the two } \\
\text { adjacent judgments }\end{array}$ & When compromise is needed \\
\hline $\begin{array}{c}\text { Reciprocals of } \\
\text { above } \\
\text { nonzero }\end{array}$ & $\begin{array}{l}\text { If activity } \mathrm{i} \text { has one of the above nonzero } \\
\text { numbers assigned to it when compared } \\
\text { with activity } \mathrm{j} \text { then } \mathrm{j} \text { has the reciprocal } \\
\text { value when compared with i. }\end{array}$ & \\
\hline
\end{tabular}

This paper proposes a three stage methodology to estimate weights for the identified dimensions of sustainability using AHP based pair wise comparison method: The first stage estimates the relative importance of three major concerns of economic, social and socio-economic performances with respect to sustainability through pair-wise comparison made between them and provides their respective weights $\mathbf{W}_{\mathrm{e}}, \mathbf{W}_{\mathrm{s}}$ and $\mathbf{W}_{\mathrm{se}, \text {, }}$ In the second stage, pair-wise comparison is made individually between the identified key performance dimensions ' $i$ ' for each sustainable concerns of economy $\mathrm{W}_{\mathrm{i}}^{\mathrm{e}}\left(\mathrm{i}=1\right.$ to4), social $\mathrm{W}_{\mathrm{i}}^{\mathrm{s}}\left(\mathrm{i}=5\right.$ to 8 ) and $\mathrm{W}_{\mathrm{i}}^{\text {se }}(\mathrm{i}=9$ to 12) and the weights of them in their category are found; In the third stage, the weights for each dimension to estimate the sustainable composite index is found by multiplying the, $\mathrm{W}_{\mathrm{i}}^{\mathrm{e}}, \mathrm{W}_{\mathrm{i}}^{\mathrm{s}}$ and $\mathrm{W}_{\mathrm{i}}^{\mathrm{se}}$ with their respective $\mathrm{W}_{\mathrm{e}}, \mathrm{W}_{\mathrm{s}}$ and $\mathrm{W}_{\mathrm{se}}$.

$$
\begin{array}{ll}
\text { i.e. } & \mathrm{W}_{\mathrm{i}}=\mathrm{W}_{\mathrm{e}} * \mathrm{~W}_{\mathrm{i}}^{\mathrm{e}}(\mathrm{i}=1 \text { to } 4) \\
& \mathrm{W}_{\mathrm{i}}=\mathrm{W}_{\mathrm{s}} * \mathrm{~W}_{\mathrm{i}}^{\mathrm{s}}(\mathrm{i}=5 \text { to } 8) \\
& \mathrm{W}_{\mathrm{i}}=\mathrm{W}_{\mathrm{se}} * \mathrm{~W}_{\mathrm{i}}^{\text {se }}(\mathrm{i}=9 \text { to } 12)
\end{array}
$$

\subsubsection{Weights for Economic, Social and Socio-Economic Sustainability}

Table IV provides the intensity of importance (Average) obtained through personal interviews with experts working in the industries and general public, normalized weights and the average of normalized weights. The

\begin{tabular}{|c|c|c|c|c|c|c|c|c|c|}
\hline & \multicolumn{3}{|c|}{ Judgment Matrix } & \multicolumn{4}{|c|}{ Normalized value } & \multirow[t]{2}{*}{ Average } \\
\hline & & $\begin{array}{l}\text { Economy } \\
\text { (E) }\end{array}$ & $\begin{array}{l}\text { Social } \\
\text { (S) }\end{array}$ & $\begin{array}{c}\text { Socio- } \\
\text { Economic } \\
\text { (SE) }\end{array}$ & $\begin{array}{l}\text { Economy } \\
\text { (E) }\end{array}$ & \multicolumn{2}{|c|}{$\begin{array}{l}\text { Social } \\
\text { (S) }\end{array}$} & \multirow{2}{*}{$\begin{array}{c}\begin{array}{c}\text { Socio- } \\
\text { Economic } \\
\text { (SE) }\end{array} \\
0.172414\end{array}$} & \\
\hline 1 & $\begin{array}{l}\text { Economy } \\
(\mathrm{E})\end{array}$ & $\mathbf{y}$ & 3 & & $1 / 4$ & 0.187512 & 0.333333 & & 0.231086 \\
\hline 2 & Social (S & $1 / 3$ & 1 & & $1 / 5$ & 0.062441 & 0.111111 & 0.137931 & 0.103828 \\
\hline 3 & $\begin{array}{l}\text { Socio- } \\
\text { Economi } \\
\text { (SE) }\end{array}$ & ic & 5 & & 1 & 0.750047 & 0.555556 & 0.689655 & 0.665086 \\
\hline & SUM & $5 \quad 1 / 3$ & 9 & & $9 / 20$ & 1 & 1 & 1 & 1 \\
\hline
\end{tabular}
normalized values are obtained by dividing by its corresponding column sum.

Table IV Weights for economic, social and socio-economic sustainability

The average value of the normalized weights for each row becomes the weight for the sustainability performance indicator of the same row and the estimated weights for them are given below.

$\begin{array}{lll}\text { Weight for economic sustainability } & \text { 'We' } & =0.231086 \\ \text { Weight for social sustainability } & \text { 'Ws' } & =0.103828 \\ \text { Weight for socio-economic sustainability, } & \text { 'Wse' } & =0.665086\end{array}$

\subsubsection{Relative importance of dimensions within their class}

Four dimensions have been identified individually to each class of sustainability. Let D1- D4, E1-E4 and F1-F4 represent the dimensions respectively for economic, social and socio-economic sustainability. Their relative importance differs within its class. Tables V - VII show the work table of the economic, social and socio-economic dimensions. 
Table V Relative importance of dimensions of economic sustainability

\begin{tabular}{|c|c|c|c|c|c|c|c|c|c|}
\hline \multirow[t]{2}{*}{ Economy } & \multicolumn{4}{|c|}{ Judgment matrix } & \multicolumn{4}{|c|}{ Normalized values } & \multirow[b]{2}{*}{$\begin{array}{c}\text { Relative } \\
\text { importance } \\
\mathrm{W}_{\mathrm{i}}^{\mathrm{e}} \\
\text { (Average } \\
\text { of the } \\
\text { normalized } \\
\text { values in } \\
\text { the row) }\end{array}$} \\
\hline & D1 & D2 & D3 & D4 & D1 & D2 & D3 & D4 & \\
\hline D1 & 1 & $1 / 2$ & $1 / 7$ & 4 & 0.097561 & 0.135135 & 0.021497 & 0.533333 & 0.196882 \\
\hline D2 & 2 & 1 & 5 & $1 / 2$ & 0.195122 & 0.270270 & 0.752695 & 0.066667 & 0.321188 \\
\hline D3 & 7 & $1 / 5$ & 1 & 2 & 0.682927 & 0.054054 & 0.150539 & 0.266667 & 0.288547 \\
\hline D4 & $1 / 4$ & 2 & $1 / 2$ & 1 & 0.024390 & 0.540541 & 0.075269 & 0.133333 & 0.193383 \\
\hline SUM & $101 / 4$ & $37 / 10$ & $69 / 14$ & $7 \quad 1 / 2$ & 1 & 1 & 1 & 1 & 1 \\
\hline
\end{tabular}

Table VI Relative importance of dimensions of social sustainability

\begin{tabular}{|c|c|c|c|c|c|c|c|c|c|}
\hline \multirow[t]{2}{*}{ Social } & \multicolumn{4}{|c|}{ Judgment matrix } & \multicolumn{4}{|c|}{ Normalized values } & \multirow[b]{2}{*}{$\begin{array}{c}\text { Relative } \\
\text { importance } \\
\mathrm{W}_{\mathrm{i}}^{\mathrm{s}} \\
\text { (Average of the } \\
\text { normalized } \\
\text { values in the } \\
\text { row) }\end{array}$} \\
\hline & E1 & E2 & $\mathbf{E 3}$ & E4 & E1 & E2 & E3 & E4 & \\
\hline E1 & 1 & 6 & 7 & $1 / 4$ & 0.188341 & 0.486500 & 0.608696 & 0.072464 & 0.339000 \\
\hline E2 & $1 / 6$ & 1 & 3 & $1 / 5$ & 0.031390 & 0.081083 & 0.260870 & 0.057971 & 0.107828 \\
\hline E3 & $1 / 7$ & $1 / 3$ & 1 & 2 & 0.026906 & 0.027001 & 0.086957 & 0.579710 & 0.180144 \\
\hline $\mathbf{E 4}$ & 4 & 5 & $1 / 2$ & 1 & 0.753363 & 0.405416 & 0.043478 & 0.289855 & 0.373028 \\
\hline SUM & $51 / 3$ & $121 / 3$ & $111 / 2$ & $34 / 9$ & 1 & 1 & 1 & 1 & 1 \\
\hline
\end{tabular}

Table VII Relative importance of dimensions of socio-economic sustainability

\begin{tabular}{|c|c|c|c|c|c|c|c|c|c|}
\hline \multirow[t]{2}{*}{ Socio-Economic } & \multicolumn{4}{|c|}{ Judgment matrix } & \multicolumn{4}{|c|}{ Normalized values } & \multirow[b]{2}{*}{$\begin{array}{c}\text { Relative } \\
\text { importance } \\
\mathrm{W}_{\mathrm{i}}^{\mathrm{se}} \\
\text { (Average } \\
\text { of the } \\
\text { normalized } \\
\text { values in } \\
\text { the row) }\end{array}$} \\
\hline & F1 & F2 & F3 & F4 & F1 & F2 & F3 & F4 & \\
\hline F1 & 1 & $1 / 2$ & $1 / 5$ & $1 / 9$ & 0.058823 & 0.073174 & 0.021739 & 0.066667 & 0.055101 \\
\hline F2 & 2 & 1 & 3 & $1 / 5$ & 0.117647 & 0.146349 & 0.326087 & 0.133333 & 0.180854 \\
\hline F3 & 5 & $1 / 3$ & 1 & $1 / 2$ & 0.294118 & 0.048734 & 0.108696 & 0.133333 & 0.146220 \\
\hline F4 & 9 & 5 & 5 & 1 & 0.529412 & 0.731743 & 0.543478 & 0.666667 & 0.617825 \\
\hline SUM & 17 & $65 / 6$ & $91 / 5$ & $173 / 90$ & 1 & 1 & 1 & 1 & 1 \\
\hline
\end{tabular}

\subsubsection{Weights for the dimensions of sustainability}

The weights for all the 12 dimensions of sustainability are estimated using the equations 1,2 and 3 and the calculated values are given in Table VIII 
Table VIII Dimension weights

\begin{tabular}{|l|l|l|c|}
\hline $\begin{array}{l}\text { Dimension } \\
{ }^{*}{ }^{*}\end{array}$ & $\begin{array}{l}\text { Weight for individual dimensions of } \\
\text { sustainability }\end{array}$ & $\begin{array}{l}\mathrm{We}^{*} \cdot \mathrm{W}_{\mathrm{i}}^{\mathrm{e}} / \mathrm{Ws}^{*} \mathrm{~W}_{\mathrm{i}}^{\mathrm{s}} / \mathrm{Wse}_{\mathrm{se}} \\
* \mathrm{~W}_{\mathrm{i}}^{\mathrm{se}}\end{array}$ & $\mathrm{W}_{\mathrm{i}}$ \\
\hline 1. & Weight for dimension 1 of sustainability & $\mathbf{0 . 2 3 1 0 8 6} * \mathbf{0 . 1 9 6 8 8 1}$ & $\mathbf{0 . 0 4 5 4 9 6}$ \\
\hline 2. & Weight for dimension 2 of sustainability & $\mathbf{0 . 2 3 1 0 8 6} * \mathbf{0 . 3 2 1 1 8 8}$ & $\mathbf{0 . 0 7 4 2 2 2}$ \\
\hline 3. & Weight for dimension 3 of sustainability & $\mathbf{0 . 2 3 1 0 8 6} * \mathbf{0 . 2 8 8 5 4 7}$ & $\mathbf{0 . 0 6 6 6 7 9}$ \\
\hline 4. & Weight for dimension 4 of sustainability & $\mathbf{0 . 2 3 1 0 8 6} * \mathbf{0 . 1 9 3 3 8 3}$ & $\mathbf{0 . 0 4 4 6 8 8}$ \\
\hline 5. & Weight for dimension 5 of sustainability & $\mathbf{0 . 1 0 3 8 2 8} * \mathbf{0 . 3 3 9 0 0 0}$ & $\mathbf{0 . 0 3 5 1 9 8}$ \\
\hline 6. & Weight for dimension 6 of sustainability & $\mathbf{0 . 1 0 3 8 2 8} * \mathbf{0 . 1 0 7 8 2 8}$ & $\mathbf{0 . 0 1 1 1 9 6}$ \\
\hline 7. & Weight for dimension 7 of sustainability & $\mathbf{0 . 1 0 3 8 2 8} * \mathbf{0 . 1 8 0 1 4 3}$ & $\mathbf{0 . 0 1 8 7 0 4}$ \\
\hline 8. & Weight for dimension 8 of sustainability & $\mathbf{0 . 1 0 3 8 2 8} * \mathbf{0 . 3 7 3 0 2 8}$ & $\mathbf{. 0 3 8 7 3 1}$ \\
\hline 9. & Weight for dimension 9 of sustainability & $\mathbf{0 . 6 6 5 0 8 6} * \mathbf{0 . 0 5 5 1 0 1}$ & $\mathbf{. 0 3 6 6 4 7}$ \\
\hline 10. & Weight for dimension 10 of sustainability & $\mathbf{0 . 6 6 5 0 8 6} * \mathbf{0 . 1 8 0 8 5 4}$ & $\mathbf{0 . 1 2 0 2 8 3}$ \\
\hline 11. & Weight for dimension 11 of sustainability & $\mathbf{0 . 6 6 5 0 8 6} * \mathbf{0 . 1 4 6 2 2 0}$ & $\mathbf{0 . 0 9 7 2 4 9}$ \\
\hline 12. & Weight for dimension 12 of sustainability & $\mathbf{0 . 6 6 5 0 8 6} * \mathbf{0 . 6 1 7 8 2 5}$ & $\mathbf{0 . 4 1 0 9 0 7}$ \\
\hline
\end{tabular}

\subsection{Construction of Evaluation matrix for Composite Performance Index}

It is difficult to get quantitative figures for the dimensions from the industries. The performance of each dimension is collected through qualitative statements from the responsible respondents. The statements are coined such a way that they are choice based, and the respondent is able to choose and provide instant answers to all the dimensions. Five choices are picked for each dimension to indicate the performance level of the industry with respect to that dimension. They are further arranged such that the performance level increases as the choice moves from left to right. However, the qualitative information requires some sort of conversion into quantitative scores to evolve any meaningful composite index. The performance score $\mathrm{S}_{\mathrm{i}}{ }^{\mathrm{k}}$ for $\mathrm{i}^{\text {th }}$ dimension to its $\mathrm{k}^{\text {th }}$ level is valued in the range 1-5. Tables IX - XI illustrate the performance levels and scores agreed for economic, social and socio-economic measures.

Table IX Score Matrix for Economic Performance Dimensions

\begin{tabular}{|l|l|c|c|c|c|c|}
\hline Dimension identifier & Dimension (i) & \multicolumn{4}{|c|}{ Performance Level (k) } \\
\cline { 2 - 7 } & & 1 & 2 & 3 & 4 & 5 \\
\hline D1. & Income / profit (1) & $\begin{array}{c}\text { Poor } \\
(1)\end{array}$ & $\begin{array}{c}\text { Below average } \\
(2)\end{array}$ & $\begin{array}{c}\text { Average } \\
(3)\end{array}$ & $\begin{array}{c}\text { Above average } \\
(4)\end{array}$ & $\begin{array}{c}\text { Excellent } \\
(5)\end{array}$ \\
\hline D2. & Production (2) & $\begin{array}{c}\text { Poor } \\
(1)\end{array}$ & $\begin{array}{c}\text { BelowAverage } \\
(2)\end{array}$ & $\begin{array}{c}\text { Average } \\
(3)\end{array}$ & $\begin{array}{c}\text { Above average } \\
(4)\end{array}$ & $\begin{array}{c}\text { Excellent } \\
(5)\end{array}$ \\
\hline D3. & Turn over (3) & $\begin{array}{c}\text { Poor } \\
(1)\end{array}$ & $\begin{array}{c}\text { Below average } \\
(2)\end{array}$ & $\begin{array}{c}\text { Average } \\
(3)\end{array}$ & $\begin{array}{c}\text { Above average } \\
(4)\end{array}$ & $\begin{array}{c}\text { Excellent } \\
(5)\end{array}$ \\
\hline D4. & $\begin{array}{l}\text { Return on Investment } \\
(4)\end{array}$ & $\begin{array}{c}\text { Poor } \\
(1)\end{array}$ & $\begin{array}{c}\text { Below average } \\
(2)\end{array}$ & $\begin{array}{c}\text { Average } \\
(3)\end{array}$ & $\begin{array}{c}\text { Above average } \\
(4)\end{array}$ & $\begin{array}{c}\text { Excellent } \\
(5)\end{array}$ \\
\hline
\end{tabular}

Average during last five years: Poor $=-30 \% \square$, Below average $=-29 \%$ to $-6 \%$, Average $=-5 \%$ to $5 \%$, Above average $=6 \%-29 \%$, Excellent $=\square 30 \%$

Table X Score Matrix for Social Performance Dimensions

\begin{tabular}{|c|c|c|c|c|c|c|}
\hline \multirow[t]{2}{*}{ Dimension identifier } & \multirow[t]{2}{*}{ Dimension (i) } & \multicolumn{5}{|c|}{ Performance Level (k) } \\
\hline & & 1 & 2 & 3 & 4 & 5 \\
\hline E1. & Increase in Literacy Rate (5) & $\begin{array}{l}\text { Very Low } \\
\text { (1) }\end{array}$ & $\begin{array}{l}\text { Low } \\
(2)\end{array}$ & $\begin{array}{l}\text { Medium } \\
\text { (3) }\end{array}$ & $\begin{array}{l}\text { High } \\
\text { (4) }\end{array}$ & $\begin{array}{l}\text { Very High } \\
\text { (5) }\end{array}$ \\
\hline $\mathrm{E} 2$. & Drop in Accidental Rate (6) & $\begin{array}{l}\text { Very Low } \\
\text { (1) }\end{array}$ & $\begin{array}{l}\text { Low } \\
(2)\end{array}$ & $\begin{array}{l}\text { Medium } \\
\text { (3) }\end{array}$ & $\begin{array}{l}\text { High } \\
\text { (4) }\end{array}$ & $\begin{array}{l}\text { Very High } \\
\text { (5) }\end{array}$ \\
\hline E3. & Fall in Crime Rate (7) & $\begin{array}{l}\text { Very Low } \\
\text { (1) }\end{array}$ & $\begin{array}{l}\text { Low } \\
(2)\end{array}$ & $\begin{array}{l}\text { Medium } \\
\text { (3) }\end{array}$ & $\begin{array}{l}\text { High } \\
\text { (4) }\end{array}$ & $\begin{array}{l}\text { Very High } \\
\text { (5) }\end{array}$ \\
\hline E4. & 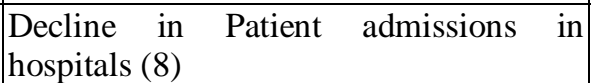 & $\begin{array}{l}\text { Very Low } \\
\text { (1) }\end{array}$ & $\begin{array}{l}\text { Low } \\
(2)\end{array}$ & $\begin{array}{l}\text { Medium } \\
\text { (3) }\end{array}$ & $\begin{array}{l}\text { High } \\
\text { (4) }\end{array}$ & $\begin{array}{l}\text { Very High } \\
\text { (5) }\end{array}$ \\
\hline
\end{tabular}

Proportional Change during last five years: Very low $=\mathbf{- 3 0} \% \square$, Low $=-29 \%$ to $\mathbf{- 6 \%}$, Medium $=\mathbf{- 5} \%$ to $5 \%$, High $=6 \%-29 \%$, Very High $=\square 30 \%$ 


\begin{tabular}{|c|c|c|c|c|c|c|}
\hline \multirow{2}{*}{$\begin{array}{c}\text { Dimension } \\
\text { identifier }\end{array}$} & \multirow[t]{2}{*}{ Dimension (i) } & \multicolumn{5}{|c|}{ Performance Level (k) } \\
\hline & & 1 & 2 & 3 & 4 & 5 \\
\hline F1. & $\begin{array}{l}\text { Per capita income increased every } \\
\text { year (9) }\end{array}$ & $\begin{array}{l}\text { Very } \\
\text { probably not } \\
(1)\end{array}$ & $\begin{array}{l}\text { Probably } \\
\text { not } \\
\text { (2) }\end{array}$ & $\begin{array}{l}\text { Probably } \\
\text { (3) }\end{array}$ & $\begin{array}{l}\text { Very } \\
\text { probably } \\
(4)\end{array}$ & $\begin{array}{c}\text { Definitely } \\
\text { (5) }\end{array}$ \\
\hline F2. & $\begin{array}{l}\text { Transport and communication } \\
\text { facilities has improved (10) }\end{array}$ & $\begin{array}{l}\text { Very } \\
\text { probably not } \\
\text { (1) }\end{array}$ & $\begin{array}{l}\text { Probably } \\
\text { not }\end{array}$ & $\begin{array}{l}\text { Probably } \\
\text { (3) }\end{array}$ & $\begin{array}{l}\text { Very } \\
\text { probably } \\
(4)\end{array}$ & $\begin{array}{c}\text { Definitely } \\
\text { (5) }\end{array}$ \\
\hline F3. & $\begin{array}{l}\text { Regularity of the employee is } \\
\operatorname{good}(11)\end{array}$ & $\begin{array}{l}\text { Very } \\
\text { probably not } \\
\quad(1)\end{array}$ & $\begin{array}{l}\text { Probably } \\
\text { not } \\
\quad(2)\end{array}$ & $\begin{array}{l}\text { Probably } \\
\text { (3) }\end{array}$ & $\begin{array}{l}\text { Very } \\
\text { probably } \\
(4)\end{array}$ & $\begin{array}{c}\text { Definitely } \\
\text { (5) }\end{array}$ \\
\hline F4. & $\begin{array}{l}\text { Unity and Morale of the } \\
\text { employees are high (12) }\end{array}$ & $\begin{array}{l}\text { Very } \\
\text { probably not } \\
\quad(1)\end{array}$ & $\begin{array}{l}\text { Probably } \\
\text { not } \\
\text { (2) }\end{array}$ & $\begin{array}{c}\text { Probably } \\
\text { (3) }\end{array}$ & \begin{tabular}{|l} 
Very \\
probably \\
$(4)$
\end{tabular} & $\begin{array}{c}\text { Definitely } \\
\text { (5) }\end{array}$ \\
\hline
\end{tabular}

Let $S_{j}{ }_{j}$ indicates the performance score obtained by the $j^{\text {th }}$ industry to the $i^{\text {th }}$ dimension. The decision matrix thus obtained for the determination of CPI for sustainability is given in the Table XII. With the evaluation matrix, different industries can be evaluated. The CPI [j] for the $\mathrm{j}^{\text {th }}$ industry is estimated in the scale of 1-100 using the equation 4 given below.

CPI $[\mathrm{j}]=20 * \sum\left(\mathrm{W}_{\mathrm{i}} * \mathrm{~S}_{\mathrm{j}}^{\mathrm{i}}\right)$

Table XII Decision matrix for CPI for sustainability

\begin{tabular}{|c|c|c|c|c|c|c|c|}
\hline \multirow{2}{*}{ Criterion(i) } & \multirow{2}{*}{ Weight $\mathrm{W}_{\mathrm{i}}$} & \multicolumn{6}{|c|}{ Industry 'j' } \\
\hline & & 1 & 2 & & $\mathrm{j}$ & & $\mathrm{n}$ \\
\hline & & $\mathrm{S}_{1}{ }^{1}(1-5)$ & $S_{2}{ }^{1}(1-5)$ & S.. ${ }^{1}(1-5)$ & $S_{j}{ }^{1}(1-5)$ & S.. ${ }^{1}(1-5)$ & ${ }^{1}{ }^{1}(1-5)$ \\
\hline & & $S_{1}^{2}(1-5)$ & $\mathrm{S}_{2}{ }^{2}(1-5)$ & S... ${ }^{2}(1-5)$ & $\mathrm{S}_{\mathrm{j}}^{2}(1-5)$ & S.. ${ }^{2}(1-5)$ & 5) \\
\hline & & $\mathrm{S}_{1}^{3}(1-5)$ & $\mathrm{S}_{2}{ }^{3}(1-5)$ & $\mathrm{S} . .^{3}(1-5)$ & $\mathrm{S}_{\mathrm{j}}^{3}(1-5)$ & S.. ${ }^{3}(1-5)$ & $\mathrm{S}_{\mathrm{n}}^{3}(1-5)$ \\
\hline & & $1^{4}(1-5)$ & $\mathrm{S}_{2}{ }^{4}(1-5)$ & S.. ${ }^{4}(1-5)$ & $\mathrm{S}_{\mathrm{j}}^{4}(1-5)$ & S.. ${ }^{4}(1-5)$ & $\mathrm{S}_{\mathrm{n}}^{4}(1-5)$ \\
\hline & & & & & & S.. ${ }^{5}(1-5)$ & \\
\hline & & & $\mathrm{S}_{2}{ }^{6}(1-5)$ & S.. ${ }^{6}(1-5)$ & $S_{j}^{6}(1-5)$ & S.. ${ }^{6}(1-5)$ & $\mathrm{S}_{\mathrm{n}}{ }^{6}(1-5)$ \\
\hline & & $(1-5)$ & $\mathrm{S}_{2}^{7}(1-5)$ & S.. ${ }^{7}(1-5)$ & $S_{j}^{7}(1-5)$ & S.. ${ }^{7}(1-5)$ & $\mathrm{S}_{\mathrm{n}}^{7}(1-5)$ \\
\hline & & $(1-5)$ & $\mathrm{S}_{2}{ }^{8}(1-5)$ & $\mathrm{S} .^{8}(1-5)$ & $\mathrm{S}_{\mathrm{j}}^{8}(1-5)$ & S.. ${ }^{8}(1-5)$ & \\
\hline & & $9(1-5)$ & $\mathrm{S}_{2}{ }^{9}(1-5)$ & S.. ${ }^{9}(1-5)$ & $\mathrm{S}_{\mathrm{j}}{ }^{9}(1-5)$ & S.. ${ }^{9}(1-5)$ & $\mathrm{S}_{\mathrm{n}}{ }^{9}(1-5)$ \\
\hline & & $\mathrm{S}_{1}{ }^{10}(1-5)$ & $\mathrm{S}_{2}{ }^{10}(1-5)$ & S.. ${ }^{10}(1-5)$ & $S_{j}^{10}(1-5)$ & S.. ${ }^{10}(1-5)$ & $\mathrm{S}_{\mathrm{n}}^{10}(1-5)$ \\
\hline & & $\mathrm{S}_{1}{ }^{11}(1-5)$ & $\mathrm{S}_{2}{ }^{11}(1-5)$ & $\mathrm{S} .{ }^{11}(1-5)$ & $\mathrm{S}_{\mathrm{j}}{ }^{11}(1-5)$ & S.. ${ }^{11}(1-5)$ & $\mathrm{S}_{\mathrm{n}}{ }^{11}(1-5)$ \\
\hline $44(12)$ & 0.410907 & $\mathrm{~S}_{1}{ }^{12}(1-5)$ & $\mathrm{S}_{2}{ }^{12}(1-5)$ & S.. ${ }^{12}(1-5)$ & $S_{j}^{12}(1-5)$ & S.. ${ }^{12}(1-5)$ & $\mathrm{S}_{\mathrm{n}}{ }^{12}(1-5)$ \\
\hline
\end{tabular}

\section{Discussions}

The method of finding CPI for sustainability is illustrated with the data collected through questionnaire from industrial respondents. Table XIII provides the performance score data of ten industries to twelve identified dimensions of sustainability along with their CPI for sustainability. The performance with respect to sustainability heavily depends on the scores of the socio-economic sustainability. This is due to the fact that the weight for socio-economic factor is comparatively higher than other two factors of economy and social sustainability. With respect to social concerns, the contributions are more significant than economical aspect. The more environmental concerns that are directly contributing to socio-economic performance are critical and deciding factor of sustainable performance of industries. 


\begin{tabular}{|c|c|c|c|c|c|c|c|c|c|c|c|}
\hline & & Table & AII & rtorma & Ice sco & e and & PI for & stamat & & & \\
\hline Criterio & & & & & & & ustry 'j' & & & & \\
\hline $\begin{array}{l}\mathbf{n} \\
\text { (i) }\end{array}$ & $\mathbf{W}_{\mathbf{i}}$ & 1 & 2 & 3 & 4 & 5 & 6 & 7 & 8 & 9 & 10 \\
\hline D1 (1) & 0.045497 & 3 & 4 & 5 & 5 & 5 & 3 & 4 & 5 & 3 & 4 \\
\hline $\mathrm{D} 2(2)$ & 0.074222 & 4 & 4 & 4 & 5 & 4 & 4 & 5 & 4 & 4 & 5 \\
\hline D3 (3) & 0.066679 & 3 & 5 & 5 & 4 & 4 & 5 & 4 & 5 & 3 & 5 \\
\hline D4 (4) & 0.044688 & 5 & 4 & 4 & 5 & 4 & 4 & 4 & 4 & 4 & 5 \\
\hline E1 (5) & 0.035198 & 4 & 3 & 4 & 3 & 5 & 3 & 5 & 4 & 5 & 5 \\
\hline E2 (6) & 0.011196 & 5 & 5 & 3 & 3 & 5 & 3 & 5 & 4 & 5 & 5 \\
\hline E3 (7) & 0.018704 & 4 & 4 & 5 & 5 & 5 & 4 & 3 & 3 & 4 & 4 \\
\hline E4 (8) & 0.038731 & 4 & 5 & 4 & 5 & 3 & 4 & 5 & 5 & 5 & 5 \\
\hline F1 (9) & 0.036647 & 3 & 5 & 4 & 2 & 4 & 5 & 4 & 4 & 4 & 5 \\
\hline F2 (10) & 0.120284 & 5 & 5 & 5 & 3 & 5 & 4 & 2 & 4 & 3 & 5 \\
\hline F3 (12) & 0.097249 & 4 & 4 & 4 & 2 & 4 & 3 & 3 & 4 & 5 & 5 \\
\hline F4 (12) & 0.410907 & 4 & 4 & 4 & 3 & 5 & 3 & 3 & 5 & 5 & 4 \\
\hline CPI [j] & & 80.55 & 84.77 & 84.80 & 67.53 & 92.06 & 70.06 & 67.83 & 90.86 & 87.21 & 90.49 \\
\hline
\end{tabular}

\section{Conclusions}

In this paper, the dimensions that are key for the sustainable performance assessment of the industries are identified. The relative importance sustainability is determined applying pair wise comparison methodology. The performance score for each dimension is established, and the decision matrix is established to estimate a CPI for sustainability. The application of the proposed CPI is illustrated with case study examples. The CPI developed for sustainability can be useful for assessing the performance of industries as well identifying environmental practices to be followed for their sustainability. The discussions reveal that sustainable performance depends mostly on socio-economic performance of any manufacturing industry. However, this could not be accepted as such, since the results are based on the estimated weights. This necessitates further works to concentrate on development of more accurate techniques for weights determination. Besides, there are more environmental concerns that contribute directly to socio-economic performance and they could be included in future studies.

\section{Acknowledgement:}

We thank University Grants Commission for sanctioning the project entitled "Exploration and Development of Environmental Regulation Management Systems in Indian Manufacturing Industries F.No.38249/2009 (SR) 24th Dec 2009 along with the financial support for carrying out this project. Also we extend our thanks to the Management of Thiagarajar College of Engineering, Madurai, for the lab facilities provided to carry the project. Besides, we thank the industrial experts of various organizations for their contribution in framing the questionnaire.

\section{References}

[1] Black, A, The Quest for Sustainable, Healthy Communities. Presentation to the Effective Sustainability Education Conference, 19th Feb, NSW Council on Environmental Education, UNSW, (2004), Sydney Feb 18-20.

[2] Brundtland Report, (1987), Available at:http://conspect.nl/pdf/Our_Common_Future-Brundtland_Report_1987.pdf

[3] Donatiello G, Environmental Sustainability Indicators in Urban Areas: An Italian Experience Environment Methodology and Statistics Project, National Statistical Institute of Italy (2001).

[4] Hizsnyik E and Toth F L, Integrating Mainstream Economic Indicators with Sustainable Development Objectives, International Institute for Applied Systems Analysis, (2010).

[5] Gilbert N, Lucas L, Klein C, Menager M, Bonnet N, and Ploton D. Three-dimensional co-location of rna polymerase 1 and dna during interphase and mitosis by confocal microscopy. Journal of Cell Science, (1995), vol.108: pp.115-125.

[6] Gimenez TC. Sierra, V. and Rodon J. Sustainable operations: Their impact on the triple bottom line. International Journal of Production Economics, (2012), vol.140 (1), pp.149-159.

[7] Goodland, R. "The Concept of Environmental Sustainability." Annual Review of Ecology and Systematic (1995), (26): 1-24

[8] Hanley N, Moffatt I, Faichney R and Wilson M. Measuring sustainability: a time series of alternative indicators for Scotland, Journal of Ecological Economy, (1999), vol.28, pp.55-73.

[9] Hamrin R D, Renewable natural resources; Conservation of natural resources, Praeger publishers, (1983), Book Chapter xi, 174 p, ISBN 0030637538. 
[10] Holdren JP, Daily GC, Ehrlich PR. The meaning of sustainability: Biogeophysical aspects. In: Munasinghae, M., Shearer, W. (Eds.), Defining and Measuring Sustainability, World Bank, Washington, D.C. (1995) pp. 3- 17.

[11] Herrmann, M. "Rethinking the link between labour market flexibility and corporate competitiveness: a critique of the Institutionalist literature." Socio-Economic Review, (2008), Vol. 6 (4): pp. 637-669.

[12] Kellen V, Business Performance Measurement, At the Crossroads of Strategy, Decision-Making, Learning and Information Visualization, Feb, (2003).

[13] Keeney and Raiffa L, utility functions for Multiattributed Consequences, Management Science, (1976), Vol.18, pp.276-87.

[14] Martin R, "Measuring Aggregate Welfare in Developing Countries: How Well Do National Accounts and Surveys Agree?". The Review of Economics and Statistics, MIT Press, vol. 85(3), pp: 645-652, August (2003).

[15] Markandya A and Pearce D. "Natural Environments and the Social Rate of Discount." Project Appraisal. (1988). Vol 3 (1).

[16] Prescott-Allen, R. The Wellbeing of Nations. A country-by-Country Index of Quality of Life and the Environment. Island Press. (2001) pp.341.

[17] Sutton P, A perspective on environmental sustainability? A paper for the Victorian Commissioner for environmental sustainability, (2004),

available online athttp://www.ces.vic.gov.au/ces/wcmn301.nsf/obj/ cesplan/\$file/A+Perspective+on+environmental+sustainbility.pdf

[18] Saaty, T.L. (1980), The Analytic Hierarchy Process, New York: McGraw Hill. International, Translated to Russian, Portuguese, and Chinese, Revised editions, Paperback (1996, 2000), Pittsburgh: RWS Publications.

[19] San Cristóbal Mateo J. R., Multi-Criteria Analysis in the Renewable Energy Industry, Green Energy and Technology, (2012), DOI: 10.1007/978-1-4471-2346-0_2, Springer-Verlag London Limited.

[20] Serageldine I, Streeter A. Valuing the environment: proceedings of the first annual conference on environmental sustainable development. Environmentally sustainable development proceedings, series No. 2, The World Bank, Washington, D.C. (1993)

[21] Tanguay, G., Rajaonson, J., Lefebvre, J-F., Lanoie, P. (2010). Measuring the sustainability of cities: An analysis of the use of local indicators, Ecological Indicators, Volume 10, Issue 2, pp. 407-418.

[22] Torjman S, The Social Dimension of Sustainable Development, Ottawa: Caledon Institute of Social Policy, May 2000, ISBN 1894598-00-8

[23] Triantaphyllou, E. and Mann, S.H., Using the hierarchy process for decision making in engineering applications: some challenges, industrial Engineering Applications and Practice, (1995), Vol.2 (1), pp. 35-44

[24] Yarong and Xin, Research on the sustainable development and the objective of Chinese government performance audit, Energy Proc (2011),

[25] WDR, Development and the Environment, World Bank and Oxford University Press, (1992), ISBN: 978-0-19-520876-4 